\section{Spedbarnsdødeligheten synker i Kina}

\author{
Langt flere fødsler i Kina skjer nå i sykehus. Spedbarnsdødeligheten \\ er kraftig redusert.
}

Siden 2000 har kinesiske myndigheter oppfordret kvinner til å føde i sykehus eller andre fødeinstitusjoner, og sykehusfødsler er nå normen i store deler av landet. En studie som nylig er publisert i The Lancet, omfattet $9 \%$ av alle levendefødte i perioden 1996-2008 og viste en reduksjon i spedbarnsdødelighet på hele $62 \%$ (1). Andel dødsfall de fire første leveukene ble redusert fra 24,7 per 1000 (i 1996) til 9,3 per 1000 (i 2007-08). Barn født i sykehus hadde 2-3 ganger lavere risiko for å dø i spedbarnsperioden enn barn født utenfor sykehus.

- Det skjer noe med verdens spedbarnsdødelighet, sier Ola Didrik Saugstad, som er professor ved Pediatrisk forskningsinstitutt, Oslo universitetssykehus. Flere land som tidligere hadde høy dødelighet, rapporterer nå om fallende dødelighetsrater. Likevel kommer ikke FNs tusenårsmål om å redusere barnedødeligheten under fem år med to tredeler innen 2015 til å bli nådd, sier

\section{Merete Kile Holtermann \\ merete.holtermann@legeforeningen.no}

\title{
Diagnostisering av tuberkulose i lavinntekts- og mellominntektsland
}

\section{IGRA-tester påviser tuberkulosesmitte, men kan ikke brukes til å skille latent fra aktiv infeksjon.}

Diagnostisering av tuberkulose kan være utfordrende. Et tilskudd det siste tiåret er såkalte IGRA linterferon-gamma release assays)-tester, som påviser T-celler sensitivisert for $\mathrm{m}$. tuberculosis. Testene er veletablert i utredningen av tuberkulose i høyinntektsland og regnes som mer spesifikke enn hudtest (Mantoux' eller Pirquets prøve), men er kostbare. De fleste studier av IGRA er gjort i høyinntekstland, og resultatene er ekstrapolert til lavinntekts- og mellominntektsland. I mange av disse landene må man prioritere behandling av aktiv tuberkulose, men IGRA kan ikke skille aktiv infeksjon fra latent tuberkulose. Man vet også at tilstander som underernæring og hivinfeksjon, svekker påliteligheten til IGRA (1).

En ny metaanalyse, som inkluderte 27 studier fra lavinntekts- og mellominntektsland, konkluderer med at IGRA ikke kan brukes til å diagnostisere aktiv tuberkulose i lavinntekts- og mellominntektsland (2). Blant hivpositive (844 pasienter) var sensitiviteten henholdsvis $76 \%$ (95\% KI 45-92\%)

og $60 \%(95 \% \mathrm{KI} 34-82 \%)$ for de to IGRAtestene; mens spesifisiteten var henholdsvis $52 \%(95 \% \mathrm{KI} \quad 40-63 \%)$ og $50 \%(95 \% \mathrm{KI}$ (590 pasienter) var spesifisitetenhenholdsvis $61 \%$ (95\% KI 40-79\%) og $52 \%$ (95\% KI 41-62\%), og det var ingen holdepunkter for at IGRA hadde bedre sensitivitet enn hudtest for å påvise aktiv tuberkulose.

\section{Kristoffer Brodwall}

kristoffer.brodwall@gmail.com

Avdeling for internasjonalt samarbeid

Haukeland universitetssykehus

\section{Litteratur}

1. WHO Policy statement: Use of tuberculosis interferon-gamma release assays (IGRAs) in low- and middleincome countries. Genève: WHO, 2011. www.who.int/tb/features archive/ policy_statement_igra_oct2011.pdf (8.2. 2012).

2. Metcalfe JZ, Everett CK, Steingart KR et al. Interferon- $\gamma$ release assays for active pulmonary tuber income countries: systematic review and metaanalysis. J Infect Dis 2011; 204 (suppl 4): 1120-9.
Saugstad. - Dette skyldes først og fremst at nyfødtdødeligheten ikke faller tilstrekkelig. Det er på dette området ressursene særlig må settes inn. På verdensbasis tar infeksjoner, for tidlig fødsel, lav fødselsvekt og fødselsasfyksi livet av rundt 3,3 millioner nyfødte hvert år.

En viktig årsak til fremgangen $\mathrm{i}$ Kina er bedre organisering og flere sykehusfødsler, mener Saugstad. - I tillegg er underernæring eliminert og infeksjoner sterkt begrenset. Den kinesiske fremgangen kan stimulere til økt innsats $\mathrm{i}$ andre land, sier han. Tidsskriftet

\section{Litteratur}

1. Feng XL, Guo S, Hipgrave D et al. China's facilitybased birth strategy and neonatal mortality: a population-based epidemiological study. Lancet 2011; 378: 1493-500.

\section{«Norsk» iktyose- variant er kartlagt}

\author{
En arvelig «norsk» hudsykdom \\ skyldes forstyrrelser i hudens fett- \\ syremetabolisme.
}

I 1980-årene oppdaget genetiker Tobias Gedde-Dahl jr. (1934-2006) og hudlege Margareta Johnsson (f. 1943) flere pasienter i Norge med en ny form for iktyose. GeddeDahl identifiserte 17 familier med slekt fra Trøndelag som hadde liknende sykehistorie og funn. Sykdommen ble kalt iktyotisk prematuritetssyndrom, da alle pasientene var født premature.

Vi har nylig beskrevet typiske prenatale ultralydfunn, klinisk forløp og diagnostiske ultrastrukturelle hudforandringer $(1,2)$. Genetiske analyser har vist at syndromet skyldes mutasjoner i en fettsyretransportør (fatty acid transporter protein 4), noe som tyder på at sykdommen skyldes forstyrret fettsyremetabolisme i huden (3).

Inntil nylig har man trodd at iktyotisk prematuritetssyndrom nesten bare forekommer i Norge, men det er nå identifisert pasienter også $\mathrm{i}$ andre europeiske land og fra Nord-Afrika, Midtøsten og Sør-Amerika. Tre av våre 23 pasienter døde kort tid etter fødselen pga. respirasjonsproblemer. Kunnskap om syndromet er derfor viktig for tidlig diagnostikk og optimal perinatal behandling. Våre funn viser en meget sterk assosiasjon mellom iktyotisk prematuritetssyndrom og allergiske sykdommer. Pasientenes hud har likhetstrekk med huden ved atopisk dermatitt, og svært mange av pasientene er allergisk mot luftveisallergener og/eller matvarer. Fremtidige studier av dette syndromet kan derfor kaste nytt lys over årsaker til allergisykdommer. $35-65 \%)$. Ved inklusjon også av hivnegative culosis diagnosis in adults in low- and middle-

\section{Frode Jahnsen}

frode.lars.jahnsen@rr-research.no

Oslo universitetssykehus, Rikshospitalet

\section{Litteratur}

1. Blaas H, Salvesen K, Khnykin D et al. Prenatal sonographic assessment and perinatal course of ichthyosis prematurity syndrome. Ultrasound Obstet Gynecol 2011; e-publisert 4.4. 2011.

2. Khnykin D, Rønnevig J, Johnsson M et al. Ichthyosis prematurity syndrome: clinical evaluation of 17 families with a rare disorder of lipid metabolism. J Am Acad Dermatol 2011; e-publisert 19.8.2011. tions in the fatty acid transport protein 4 gene cause the ichthyosis prematurity syndrome. Am J Hum Genet 2009; 85: 248-53.
3. Klar J, Schweiger M, Zimmerman R et al. Muta- 